\title{
UTILIZING ONLINE LEARNING TO ENHANCE ENGLISH SKILLS ON INTENSIVE ENGLISH CLASS
}

\author{
Tenny Murtiningsih
}

Universitas Muhammadiyah Banjarmasin

Corresponding author: tmurtiningsih28@gmail.com

\begin{tabular}{|c|c|}
\hline Article Info & Abstract \\
\hline $\begin{array}{l}\text { Received : } 03 \text { September } 2020 \\
\text { Accepted : } 12 \text { October } 2020 \\
\text { Published : } 22 \text { October } 2020\end{array}$ & $\begin{array}{l}\text { The Covid-19 pandemic has transformed the learning system. } \\
\text { The great impact on the learning system is that millions of } \\
\text { schools and universities are now starting to practice online } \\
\text { learning massively at all levels of education. Now, the online }\end{array}$ \\
\hline $\begin{array}{l}\text { Keywords: Online Learning, } \\
\text { Intensive English Class, English } \\
\text { Skills }\end{array}$ & $\begin{array}{l}\text { at one university in Banjarmasin. Intensive English Class } \\
\text { (IEC) is a one-year English program for the students. This } \\
\text { study aimed to investigate the use of online learning to } \\
\text { enhance English skills through Intensive English Class. This } \\
\text { is a qualitative descriptive study. This study invited } 339 \\
\text { freshmen students and six Intensive English Class instructors } \\
\text { as respondents. The results of this study show that online } \\
\text { learning at Intensive English Class could effectively improve } \\
\text { students English skills. This can be seen from the data that } \\
58.1 \% \text { students agreed that the online learning could help } \\
\text { them to enhance their English skills. It was also supported by } \\
\text { their knowledge of how to use online learning well. This } \\
\text { means that there is a good connection between utilizing online } \\
\text { learning and the development of English skills on Intensive } \\
\text { English Class. }\end{array}$ \\
\hline
\end{tabular}

\section{INTRODUCTION}

The Intensive English Class is a one-year English program for first year students at Universitas Muhammadiyah Banjarmasin. The objective of this program is to improve students' English skill, in particular public speaking. The learners study English for four days in a week. During Covid-19 pandemic, the teaching learning process has been transformed into an online mode. Thus, students are encouraged to study virtually through online learning system. It is because face to face class not allowed during Covid-19 pandemic. Therefore online learning is the answer for this condition. 
Online learning has been viewed differently by experts. Mukhuca (2020) states that online learning refers to electronically mediated learning including the use of computers, devices and gadgets. Those are intended make learning easier to be accessed by students.

According to Mallillin et. al (2020), online classes are lessons conducted through the use of technology and being conducted through internet. Furthermore, Kidd and Keengwe (2010) states that online learning is focused not only on the online contexts, but also includes a full range of computer based learning platforms and delivery methods, genres, formats and media such as multimedia, educational programming, simulations, games and the use of new media on fixed and mobile platforms across all discipline areas. Clearly speaking, technology is needed to support online learning. In short, the rapid evolvement of information communication technology (ICT) impacts on the development of online learning.

Technology gives positive impacts on teaching learning process. Technology has developed rapidly and now we can use different platforms for online learning. There are so many fascinating online learning platforms that can be used for online learning, such as Zoom, WhatsApp, Google Meets, Google Classroom, Google Classroom, Quizizz, Kahoot, Youtube, Canva and others. The synergy of ICT and online learning would give a new experience both for the teachers and the students in doing teaching learning process.

The existence of online learning supported by ICT offers synchronous and asynchronous teaching delivery. Asynchronous refers to instruction that is not constrained by geography or time. Everyone involved in an asynchronous activity performs his or her part on his or her own time. Synchronous refers to instruction that is led by a facilitator in real time, generally over the Internet (Jenniver, 2004). Intensive English Class only uses synchronous online learning to deal with the curriculum itself. Shortly, online teaching learning activity for Intensive English Class is just in the real time instruction.

Online learning environment offers a new virtual classroom as instructor-led synchronous computer learning environments attended by participants online at the same time but in different locations (Clark and Kwinn, 2007). A real time face to face classroom activity is changed into synchronous engagement through online learning class which is mediated by ICT. Thus, the success of online learning depends on digital skills, availability of educational technologies and good internet connection (Paschal and Mkulu, 2020).

To deal with online learning issues, ICT literacy is important to students. ICT skill is a need in order to make online learning runs well. Aljaraidah and Al Baineh (2019) 
contend that ability and confidence dealing with online learning technology is required for an online class. Lack of ICT skill may hinder the effectiveness of online learning. That idea is also supported by Jaben and Thomas (2015), they recommend that it is necessary to overcome the shortcomings of the traditional language teaching and learning methods by integrating appropriate technologies and instructional strategies in second language education field.

Another solution to the ICT literacy is by providing teachers with trainings of the using ICT English instructor needs to learn the ways to integrate technology into teaching learning strategy and design instructional. English instructor should be technologically literate. In the same vein, students as should also be equipped with good ICT skill to access their online classes.

As it has been discussed above that having good ICT skill is a supportive skill for online learning because ICT is just a medium in online language learning. More importantly, English instructor should have good language pedagogy to teach. It is because language pedagogy is the main element in an online learning.

Besides asynchronous meeting, there should be synchronous interaction between the instructor and students. This synchronous interaction includes instruction, collaboration, support, socialization and informal exchange and extended outreach (Finkelstein. 2006).

Instruction means how the instructor gives any instruction to engage students in teaching learning online. Collaboration needs to develop online learning live. This can be reached by having discussion or work together with students. Support is needed to give motivation for students in dealing with online learning. Socialization and informal exchange can be given by writing something in online chat rooms or even giving message in social contents. It is important to develop social community and engage with learners. Extended outreach is important to develop any good relation with professional development, alumni, other campuses and stake holders.

Another factor in an online learning is that we can not ignore an internet network. The internet connection also gives influence to our online learning process. Having good internet connection may support online learning interaction. Unfortunately, in a remote area this would be an issue where students may face difficulties of having a good internet connection. Another solution is the deployment of English asynchronous online class. Students are still able to access the materials online while they cannot attend the class in a real.

\section{METHODOLOGY}


This is a qualitative study to describe the utilization of online learning to enhance English skills through an Intensive English Class. This study aimed to answer two research questions: 1)How does online learning work in an Intensive English Class?; 2)Can online learning enhance English skill of students joining Intensive English Class?

The participants of this study were 339 students and 6 instructors of Intensive English Program of Universitas Muhammadiyah Banjarmasin academic year 2019/2020. They were asked their opinion about their experiences of conducting and joining online Intensive English Class during Covid-19 pandemic.

The data were garnered using questionnaires and interviews. Besides that, the researcher also conducted interviews with 6 instructors of the program. All of the data were analyzed and presented in qualitative description.

\section{FINDINGS AND DISCUSSIONS}

The discussion below is about the research findings that the researcher got from the questionnaires from students and the interview from the English instructors. The numbers below are written in percentage.

\section{The preferences of English lesson.}

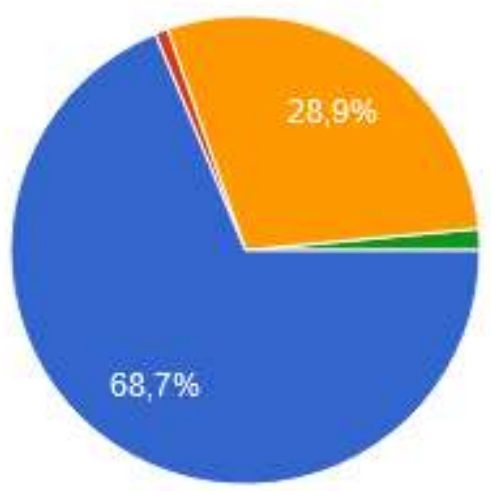

The pie chart above shows that most of the respondents $(68.7 \%)$ really love English. It is indicated by more half of the students who joined this program love English. It was also supported by the result of interviews with the instructors - some of which stated that students looked enthusiastic to participate in the online learning of intensive English Class. Students' high percentage of attendance show the same trend 
2. Whether online learning is exist in their study program before

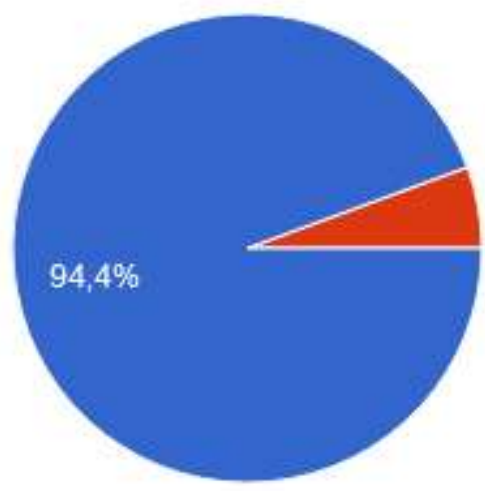

Most of respondents were familiar with online learning. They used to have online learning class in their study program even though they rarely used the method. Therefore, respondents were not surprised when Intensive English Class should be delivered in an online learning during Covid-19 pandemic. The pie shows that $94.4 \%$ of students have ever used online learning on their study program.

\section{Whether their Intensive English Class was ever delivered online}

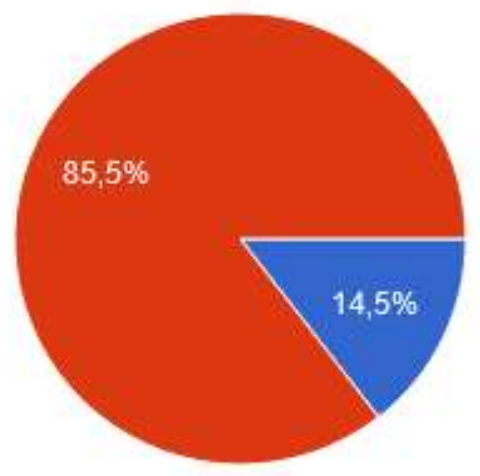

The chart shows that $85.5 \%$ of respondents never joined an online learning before Covid-19. This is because the majority of instructors prefer to use offline class to online one. Some of English instructors ever used Kahoot! and Quizizz for their Intensive English Class. They used this online learning platform just for fun at the class. They hoped that it can motivate students to learn English.

\section{Students' attendance during online learning Intensive English Class}




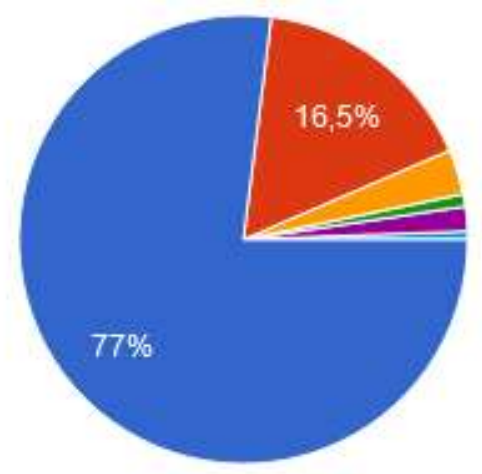

It shows that $77 \%$ of students actively join online Intensive English Class. It indicates that there was a good connection between students' English preference with their attendance at the class.

\section{Students' understanding in using any online learning platform for Intensive English Class}

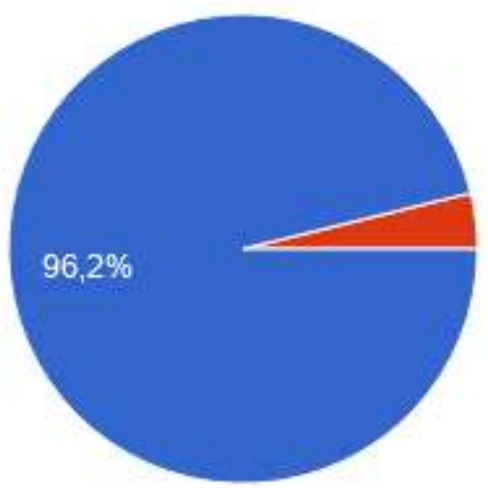

There are $96.2 \%$ of students who understand of how to use online platform for their class. Having a good understanding of using the learning apps may help the learners to integrate the teachnology into learning process. So the class will run effectively and smoothly.

The results of the interview show that most of the English Instructors introduced the online platform's name first. There were so many online platform to offer to the class, namely: Zoom, Google Meet, Google Classroom, Kahoot, Whatsapp, Quizizz and others. The English instructors just chose what online platform that suit best. In other words, teachers need to consider learners' need and appropriate online platform. After that he will explain to the students about how to download and how to operate.

Hopefully after the explanation, the students can operate it well and get familiar with this platform. 
6. Whether the use of online learning platform for Intensive English Class helps students in learning process

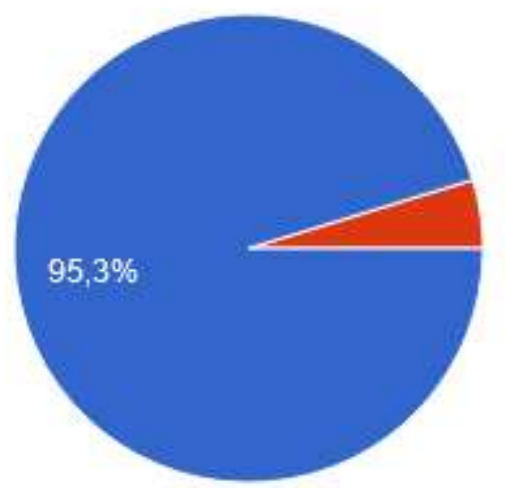

There were $95.3 \%$ of students realized that the use of online learning platform is useful to help them dealing with online learning during Covid-19 pandemic. Also, the results of interview indicate that online learning platform really worked to facilitate classroom activities. They can share the materials, do discussions and even play a game by using online learning platform.

\section{The students' obstacles during online learning Intensive English Class}

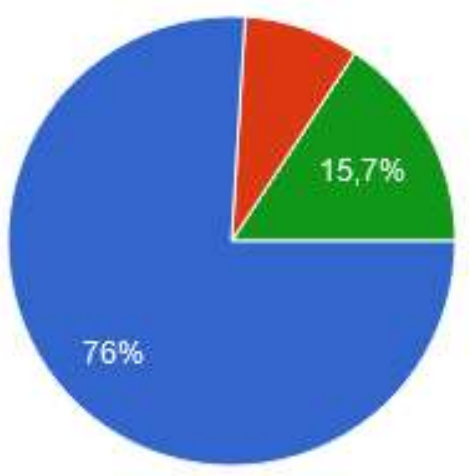

There were $76 \%$ of students agree that unstable internet network was the main obstacle for them to join online learning Intensive English Class. This is because most of them live in a remote area and difficult to get internet access. Some of the respondents shared their experience for this case. They prefer the easiest and simplest online learning platform to get effective learning process. They prefer to use Whatsapp Group as their synchronous online learning. They believe that Whatsapp was an easier online learning platform.

8. Whether online Intensive English Class is interesting to join 


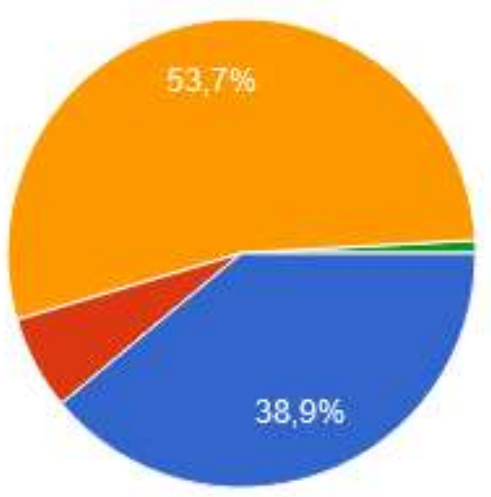

There were $53.7 \%$ of students said that Intensive English Class was interesting to join. This is because there were so many English activities performed online. These activities inspire their enthusiasm to attend the class. So, an interesting online intensive English class could improve students' motivation.

9. How the English instructor delivered the materials online in learning Intensive English Class

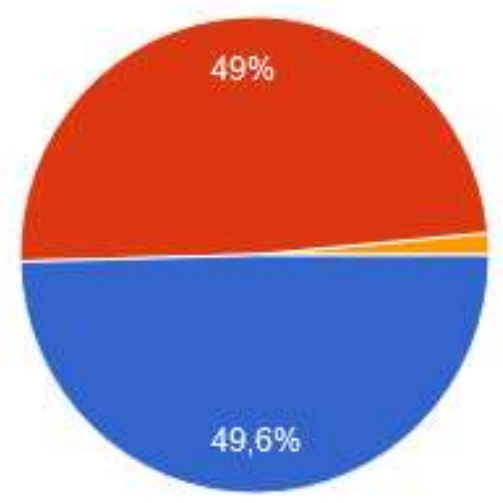

There were $49.5 \%$ of students claimed that the instructors delivered the materials with very good delivery whereas $49 \%$ of students argue that the instructors did a good teaching delivery. Hopefully, this positive feedback is used for the development of English instructor's skill in teaching. Thus, the quality of teaching learning process may increase. 
10. The use of online learning to enhance English skill of students joining Intensive English Class

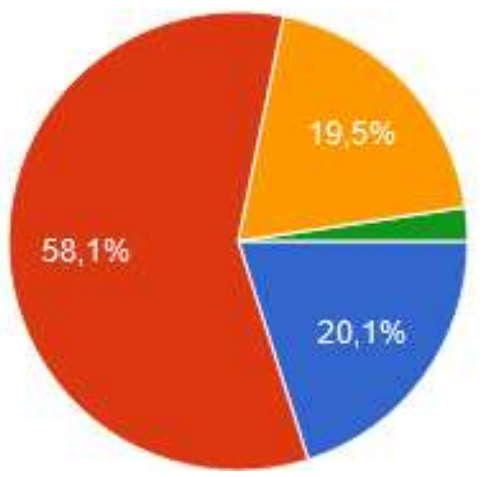

The students' responses were mostly positive. There were $58.1 \%$ of students said 'Yes' that online learning really helped them enhance their English skill . From the data, it is clearly seen that the use of online learning can enhance the students' English skill. Based on the interviews, English instructors tried to enhance the students' English skill by exploring some language activities for their online learning Intensive English Class, by using WhatsApp Group or Google Classroom, recording English voice note by using WhatsApp, explaining and discussing material by using Zoom and others.

The utilization of ICT in an online learning is so helpful. It does not only give a new learning experience but it can also enhance English skill. The use of online learning may not work well at the class when the English instructors have no good skill of language pedagogy.

\section{Which English skill is more developed after the online Intensive English Class}

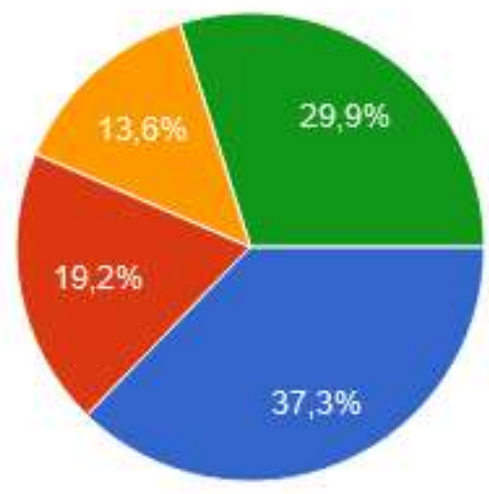

Speaking skill is the more developed skill after the online learning Intensive English Class. It was supported by $37.3 \%$ of students agreed for this. It is 
because the main goal of Intensive English Class is to develop public speaking skill. To answer this goal, the English instructor should give some speaking activities during this online learning class.

\section{Students' preferences of learning modes}

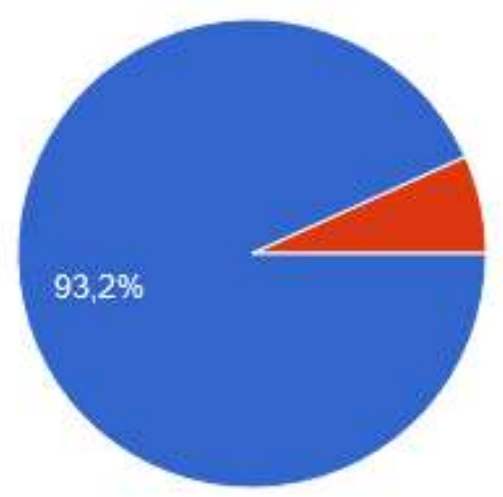

Even though they loved to have online learning and gained advantages, but in fact, they still missed a face to face class. They still prefer to have face to face class to online learning class. It was proved by $93.2 \%$ of students who contended that.

Based on the interviews with some English instructors, they also claimed that having face to face class is more effective. Some reasons they provided were that giving feedback face to face class can be done spontaneously. The class engagement can be organized better. It also makes easier to have class interaction.

Based on those research findings above, we know that the utilizing online learning really helps on Intensive English Class in this pandemic. Online learning on Intensive English Class could not run well if there was no good integration between language pedagogy and ICT skill. The competency of ICT supports language pedagogy to run online learning effectively. This collaboration also needs the availability of good internet connection so online learning for Intensive English Class could run effectively.

Because of good integration of those aspects during online learning, the data of this study indicate that online learning could enhance English skill on Intensive English Class. Findings of this study supports some previous studies (such as Paschal \& Mkulu, 2020; Aljaraidah \& Al Bairah, 2019; Jaben Thomas., 2015) that technology and language pedagogy must have good collaboration in running the online learning. Language pedagogy and knowledge of how to run online learning must support each other to run online teaching learning process. That's why the ability to operate ICT in language teaching must be developed to support language teaching in online learning. 
The implication of this research, the Intensive English Instructors' professional development in ICT must be developed. They must follow ICT development to support their teaching skills in running Intensive English Class better. Supposed to there is an engagement between teaching skills as a part of language pedagogy and ICT. This condition also cannot be separated from the learning environment around them. That is the availability of a good internet network. When these factors can work and support each other, so students' English skills can enhance better.

\section{CONCLUSION}

The development of ICT gives the positive impact to language learning. Technology can help us to create online language learning through some online learning platform. The utilization of technology can support, transform and enhance language learning. There are some online learning platforms can be used to develop online language learning. In this case, the English instructor must choose the suitable platform as a need for his class. There must be also integration between language skill and ICT skill. Training of how to use online learning optimally is also important before going to the online class. By having a good ICT skill for online learning class, it can support online learning class.

\section{REFERENCES}

Aljaraideh, Yousef \& Al Baineh, K. (2019). Jordanian Students' Barriers of Utilizing Online Learning : A Survey Study. International Education Vol 12 No 52019. ISSN 1913-9020. E-ISSN. 1913-9039. Published by Canadian Center of Science \& Education

Clark, C.R \& Kwinn, A. (2007). The New Virtual Classroom. Evidence Based Guidelines for Synchronous E Learning. Published Pfeiffer

Filkestein, J. (2006). Learning in Real Time. Jossey-Bass. A Wiley Imprint

Jaben, S.S \& Thomas, A.J. (2015). Effectiveness of Online Learning. Proceeding of The World Congress on Engineering \& Computer Science on Engineering \& Computer Science . Sanfransisco, USA

Jennifer, H. (2004). The Synchronous Trainer's Survival Guide: Facilitating Successful Live and Online Courses, Meetings \& Events. Published by Pfeiffer 
Kidd, T.T. \& Keengwe, J. (2020). Towards Best Practices in Online Learning \& Teaching in Higher Education. Merlot Journal of Online Learning \& Teaching. Vol. 6 No. 2, June 2010

Mallillin, LLD., Carag, E.A., \& Matillin, J. B. (2020). Integration of Knowledge Through Online Classes in The Learning Enhancement of Students. European Journal of Open Education \& E-Learning Studies. Vol 5 Issue 1 2020. ISSN: 2501-9120. ISSN-L: 2501-9120

Mukucha, T. (2020). Is Online Learning The Future of Education?. Retrieved from : (https://www. Researchgate.net////Publication/343686522) August 2020.

Paschal, M.J \& Mkulu, D.G. (2020). Online Classes during Covid 19 in Higher Learning Institution in Africa. Global Research in Higher Education. ISSN 2576$196 X$ (Print) ISSN 2576-1951 (Online) Vol. 3, No. 3, 2020 www.scholink.org/ojs/index.php/grhe 